\title{
Çağdaş Türk Romanında Mevlânâ Celaleddin-i Rûmî'nin Postmodern Tüketim Temelinde Yeniden Üretimi ${ }^{*}$
}

\author{
Doç. Dr. Bahset Karslı \\ Akdeniz Üniversitesi İlahiyat Fakültesi \\ Felsefe ve Din Bilimleri Bölümü \\ bkarsli@akdeniz.edu.tr
}

\author{
Muhammet Ali Özdoğan \\ Akdeniz Üniversitesi Sosyal Bilimler Enstitüsü \\ Din Sosyolojisi ABD Doktora Öğrencisi \\ ozdogana@gmail.com
}

Öz

Türk tasavvuf geleneğinin en önemli isimlerinden biri olan Mevlânâ Celaleddin-i Rûmî; düşünceleri, eserleri ve hakkında yapılan çalışmalar dolayısıyla tarihin her döneminde ilgi çeken bir fenomen olmuştur. Diğer taraftan günümüzde Mevlânâ üzerine yapılan çalışmalar onun dini, tasavvufi, felsefi, edebi yönüne yoğunlaşsa da bir kahraman olarak romanlarda yer alması, ona karşı okurların ilgisini yükseltmiştir. Mevlânâ üzerine gelişen bu popüler yönelimin farkında olan yazarlar da Mevlânâ'yı anlatan romanlar üretmiş̧ir. Ancak sanatçılar, romanlarda Mevlânâ'nın eserlerinden yaptıkları alıntıları kendine has üsluplarıyla yorumlamıştır. Mevlânâ üzerine kalem oynatanların yaşadığı dönem ile düşünce yapısı, çalışmaların içeriğini ve yapısını şekillendirmiştir. Genelde bugünün güncel meselelerinden hareket ederek Mevlânâ'nın bu sorunlara nasıl bir çözüm yolu önerdiği üzerinde yoğunlaşan yazarlar bu yolla Mevlânâ'nın mistik gücünden istifade etmişlerdir. Buradan hareketle Mevlânâ, eserlerde kimi zaman toplumun ihtiyaçları doğrultusunda güncellenirken kimi zaman da yeni bir anlatıyla tüketime alet edilmiştir. Neticede Mevlânâ'nın toplumdaki mistik karşılığı ve güncellenen anlatısı, kitap satışlarını etkilemesi denkleminde anlamlandırılmıştır. Bu çalışmada kitap sektöründe ciddi derecede satış rakamları elde eden Ahmet Ümit'in Bab-ı Esrar, Elif Şafak'ın Aşk, Sinan Yağmur'un Aşkın Gözyaşları romanında Mevlânâ'nın postmodern bir tüketim unsuru olarak kullanılması ele alınmıştır. Makale, tarihsel ve mistik roman karakterlerine olan ilgi nedeniyle Mevlânâ'nın postmodern bir söylemle tüketim merkezli ele alınışının analizini amaçlamaktadır.

Anahtar Kelimeler: Çağdaş Türk romanı, mistisizm, Mevlânâ, tüketim, postmodernizm.

\section{Reproduction of Mawlana Jalaluddin Rumi on the Basis of Postmodern Consumption in Modern Turkish Novel}

\footnotetext{
Abstract

Mawlana Jalaluddin-i Rûmi, one of the leading names of Turkish Sufi tradition, has always been an attractive phenomenon thanks to his thoughts, works and studies about him throughout history. On the other hand, while studies about Mawlana are concentrated on

* Bu makale, Doç. Dr. Bahset Karslı danışmanlığında tamamlanan Çağdaş Türk Romanında Mevlânâ'nın Postmodern Bir Tüketim Unsuru Olarak Kullanılması başlıklı Yüksek Lisans tezinden üretilmiştir. 
his religious, sufi, philosophical and literary aspects at the present time, that he is involved in novels as a hero/ character increases readers' attention to him. Authors who are well aware of this popular tendency towards Mawlana produce novels about him. However, authors reinterpret quotations from the works of Mawlana in their novels with their own styles. The mentality and the period of the novelists writing on Mawlana shape the content and the form of their studies. Authors who generally focus on how Mawlana would suggest solutions to today's current problems take advantage of his mystic power. From this point of view, in some works, Mawlana is updated in accordance with society's needs and in some other works he is abused by consumption with a new kind of narrative. Eventually Mawlana's mystic aspect in society and his updated narrative make sense with the rate affecting book selling. In this study, the use of Mawlana as a postmodern consumption element in Ahmet Umit's Bab-1 Esrar, Elif Şafak's Aşk (The Forty Rules of Love: A Novel of Rumi), Sinan Yağmur's Aşkın Gözyaşları (Tears of Love), which achieve notable sale results in the market, is examined. This article aims to analyse the consumption-centric handling of Mawlana with a postmodern discourse due to the interest of historical and mystical novel characters.

Keywords: Modern Turkish novel, mysticism, Mawlana Jalaluddin Rumi, consumption, postmodernism. 


\section{GíRiş}

Mevlânâ, Türk tarihinde, kültüründe önemli bir kişilik olarak yer edinmiştir. O hem yaşadığı döneme derin izler bırakmış hem de geride bıraktığı eserleriyle Türk toplumunun anlam dünyasına katkıda bulunmuştur. Mevlânâ'nın insanlar üzerindeki etkisi sadece Türk toplumu ile sınırlı kalmamış eserlerinin yabancı dillere çevrilmeye başlanmasıyla Avrupa ve Amerika'da tanınmaya başlandığı andan itibaren Batılıların da ilgi odağı haline gelmiştir. Mevlânâ hakkındaki eserlerin sayısında ve satış rakamlarındaki artış ise, özellikle İslamofobinin Batı dünyasında ivme kazanmasıyla yükselmiştir. Mevlânâ'nın doğumunun 800. yılı olan 2007 yılının UNESCO tarafından Mevlânâ Yılı ilan edilmesiyle hakkında her türde eser ortaya çıkmış, bilhassa onunla ilgili romanlar arka arkaya yayımlanmıştır.

Elbette yazarlar açısından Mevlânâ'nın tercih edilmesinde belirgin sebepler söz konusudur. Öncelikle tarihsel mistik kişiliklerin ve konuların yeğlenmesinde tarihî gerçekliğin romancının muhayyilesi istikametinde genişletilebilirliği önemli bir etkendir. Ayrıca bu gerçeklikten türetilmiş yeni metin, yazara okurun dünyasına tarihsel mistik damarla bağlanma olanağı verir. Yazar, elindeki bu imkânlar ölçüsünde okurun iç dünyasına seslenerek okura gerçeğin göründüğü gibi olmadığını, varlık ve olguların bir iç yüzü olduğunu anlatmaya çalışır. Yazar, bu doğrultuda alt metne başvurarak olayların asıl sebebi hakkında ipuçları verir.

Tarihsel kişiliklerin işlendiği romanlar, bu ipuçları vasıtasıyla şekillenir. Roman kişileri ve mekânları, toplumun sosyolojisi dikkate alınarak restore edilir. Ancak bu yenilemenin yazarın ideolojisinden, kitap sektörünün kendi iç dinamiklerinden ve yazarın içinde yaşadığı toplumun yaşam biçiminden bağımsız yürüdüğ̈u söylenemez. Zira edebiyatçı, içinde bulunduğu toplumun yaşam tarzından etkilenmektedir. Diğer bir ifadeyle toplumun dili, dini, kültürü; toplumsal katmanlar arasındaki ilişki biçimleri yazarın dünyasını şekillendirmektedir.

Öte yandan edebiyatçı ile toplum arasında tek taraflı bir ilişki söz konusu değildir. Sanatçı, yazdıklarıyla toplumu etkiler ve yazdıklarının toplumda oluşturacağı etkiyi hesap eder. Hiçbir edebiyatçı yazmak için yazmaz. Romancının bir toplumsal zeminde hayal ettiğinden ve hayalini kurduğu bir dünyanın varlığından söz edilebilir. Bir romanda yazar tarafından kurgulanan olaylar, kişiler ve zamandan hareketle bu dünyaya ulaşılabilir. Zira roman, yazarın dünyasına giden yoldur. Romancı bu dünyayı kurgu yoluyla oluşturur. Edebiyatçı kurgu dünyasına; tasarladığı karakterler, isimler, mekânlar, olaylar ve zaman vasıtasıyla somutluk kazandırır. Ancak yazar bu vasıtaları dış dünyada olduğu haliyle değil kendi iç dünyasının süzgecinden geçirerek şekillendirir.

Bütün bu iç ve dış faktörlerin yanında bir romanın ortaya çıkışında onun yapısını belirleyen temel ölçütlerin arasında dönemin piyasa koşulları da göz ardı edilemeyecek bir husustur. Mistik ve tarihsel öğelerin yoğun bir biçimde işlendiği 2000 sonrası Türk romanına özgüllü̈̆ünü veren gerçek de bu bağlamda incelenmelidir.

Bu makale, Bab-ı Esrar, Aşk, Aşkın Gözyaşları romanlarıyla sınırlandırılmıştır. Makale üç ana bölüme ayrılmıştır. Birinci bölümde postmodernitenin tüketim sürecinde dine nasıl bir misyon yüklediği üzerinde durulmuştur. İkinci bölümde Mevlânâ'dan yapılan alıntılarda yazarların Mevlânâ hakkında hangi noktalarda ortaklaştıkları ve ayrıştıkları hususlar tartışılmış; üçüncü bölümde ise yazarların gündelik hayatta okurla kurduğu ilişki tipinin popüler düzeydeki görünümüne odaklanılmıştır. Ayrıca yazarların okurla iletişimine olumlu katkı yapan üsluplarının Mevlânâ'dan ne şekilde etkilendiği; metinler arası 
gelgitlerden üretilmiş dinler arası, dinler üstü, mezhepler üstü Mevlânâ portrelerinin hangi perspektiften oluşturulduğu makalede cevabı aranan sorular arasındadır.

Toplumsal davranışa kaynaklık eden din, postmodernizm, tüketim vb. kavramların yer aldığ 1 bir konunun araştırılmasında her şeyden önce toplumsal davranışa kaynaklık eden anlamların kökenine dikkat etmek gerekmektedir. Toplumsal etkileri olan bir eylemin/durumun sonucunda ne olup bittiğini anlamak isteyen kişi, bu eyleme/duruma katılanların onu nasıl anlamlandırdıklarını, onların dürtü ve niyetlerinin ne olduğunu ve kendilerinin ya da başkalarının davranışlarının ahlaki sonuçlarını nasıl değerlendirdiklerini anlamak zorundadır (Çiftçi 1999: 16). Ancak bir davranışın sonuçlarını değerlendirirken öznel yargilara düşme tehlikesi daima mevcuttur. İnsan bilincinde hayatiyet kazanan anlamın (Berger-Luckmann 2015: 20) ikili karmaşık yapısı, araştırmanın içinde din ve dindarlık kavramlarının bulunması gibi değişkenler araştırma zeminindeki tuzakları daha da artırmaktadır. Dahası araştırmanın içinde "üzerinde tartışılması ve karara bağlanması en güç konulardan" (Emre 2004: 28) biri olan postmodernizm kavramının varlığı başka bir handikaptır. Bu tuzaklara düşmemek için araştırmanın yöntemsel çerçevesinde Bergerci fenomenolojik okuma önemli bir yer tutmaktadır. Bu itibarla, toplumu etkileme ve yönlendirme gücüne sahip Mevlânâ'nın postmodern bir söylemle tüketim temelinde ele alınışının analizi yapılmıştır.

\section{TÜRKIYYE ÖZELINDE DININ TÜKETIM LEHINE GERI DÖNÜŞÜ(MÜ): TÜKETIMINN POSTMODERN İSTIMLÂK ALANLARI}

Tüketim, insanın içinde bulunduğu dönemsel, sosyal, ekonomik, iklim ve coğrafi şartlara göre ihtiyaç duyduğu mal ve hizmeti kullanmasıdır. Tüketimin özne nesne arasında bir ilişki olması bağlamında, birey ve tüketim bağlantısında karşılıklı bir etkileşim söz konusudur. Öyle ki etrafında şekillenen koşullardan bağımsız olmaması nedeniyle insan, tüketimle olan ilişkisinde hem özne hem nesne konumundadır. Zira Berger'in (2015: 52) formüle ettiği şekilde kişinin toplumsal dünyayı şekillendiren ve o dünyanın içinde şekillenen bir varlık olması dolayısıyla söz konusu kavram insanın öznel dünyasına anlam kattığı bir basamaktır.

Tüketim, insanlık tarihi boyunca toplumu ve insanı açılamada kullanılan iktisadi, sosyolojik, psikolojik, felsefi bir kavramdır. Tüketimin tanımı, sadece maddi boyutuyla değil insanların, toplumların hayatına anlam katan bir araç olması dolayısıyla da toplumların analizi, açıklaması tüketim biçimleri ve ilişkileri üzerinden yapılmıştır. Örneğin İslami literatürde İbn Haldûn bahse konu kavram hakkında zarurat, haciyat, kemaliyat diye bir sinıflama yapmıştır (İbn Haldûn 2009: 204). İbn Haldûn'un yaptığı bu sinıflandırma hadarî, bedevî toplumun da temelini oluşturur. Max Weber (2004: 85) "sınıf" tabakalaşması, üretim ve mülkiyet ilişkilerine, "statü" tabakalaşması ise özel "hayat tarzlarının" temsil ettiği tüketim biçimlerine göre belirlenir diyerek yaşam tarzı, statü tabakalaşması ve tüketim arasında bir köprü kurmuştur. Ancak bu köprü hala ayakta olsa da zamanla tüketim biçimleri ve algılaması farklılaşmıştır. Gerek kültürel gerekse dini söyleme dair istimlâk alanları el değiştirmiştir. Bu anlamda bir zamanlar dindarlar tarafından israf olarak algılanan tüketim eylemi, dindar orta sınıfın ihtiyaçlarının çeşitliliğinin artmasıyla gereklilik olarak anlaşılmaya başlanmıştır.

Tüketimi hiyerarşik bir ilerleme olarak ele alan yaklaşımlar da olmuştur. İhtiyaçlar Hiyerarşisi adını verdiği insan psikolojisi teorisinde insanın ihtiyaçlarını karşılamak için hiyerarşik bir düzene uyduğunu savunan Maslow'un sosyolojideki ilerlemeci toplumsal 
değişim kuramlarına benzer bir mantıkla oluşturduğu teorisine göre ekonomik tüketim eksenli bir sınıfsal ayrıştırma söz konusudur. Katı modern dönemde tüketimin hiyerarşik yapısına yapılan bu vurgu Bauman'ın (2017) akışkan modernite diye tarif ettiği dönemde yaşam tarzına kaymıştır. Bauman, geçmişte filozofların "insanların yaşamak için mi çalıştı̆̆ yoksa çalışmak için mi yaşadığı?" sorusunu bu dönemde "insanın yaşamak için mi tükettiği tüketmek için mi yaşadığı?" şeklinde güncelledikten sonra yaşam tarzı ve tüketim ilişkisi arasında bir bağ kurmuştur (Bauman 2012: 82-85).

Yaşam tarzı, bireysel tercih veya eğilimlere bağlı basit bir mesele değildir. Göle'de (2011: 32) yaşam tarzı meselesi; habitusa bağlı kişiler arası, sınıfsal ve iktidar ilişkilerini ifşa eden bir konu olarak ele alınır. Yaşam tarzı, toplumsal olanın nesnel ve öznel süreçleri bütünleştirdiği, her ikisi arasında bir bağ kuran, çoklu yönleri olan bir yapıdır. Yaşam biçimi genel anlamda nesnel ve öznel sürecin içerisinde şekillenir. Hayat şeklinin belirlenmesinde tüketimin çoğulcu bir etkisi söz konusudur. Tüketici, satın aldığı ürün ile kendi yaşam planlamasının ürünlerini de seçmiş olur. Kişinin kendi geleceğine dair yönelimlerde karar aşamasında haz duygusu, kültür; estetik ve moral değerler kültürün özellikleri olarak harekete geçiricidir.

Postmodernizmle birlikte yaşam tarzındaki çeşitlilik nedeniyle kültür de tüketim bahsine dâhil edilebilir. Özellikle mimari ve edebiyatta üst anlatılara inanılmazlık (Serdar 2001: 7; Featharson 2007: 36; Bauman 2011: 193) şeklinde ortaya çıkan postmodernizmde popülizm üzerine kurulu çeşitlilik ve çokluk vardır. Modernitede dışlanan, marjinalleştirilen dünyalar açısından postmodernizm öteki seslerin ve dünyaların anlaşılmasına vurgu yapar. Postmodernizmdeki bu çokluk ve çeşitlilik ise yeni tüketim pratiklerine yön verir (Serdar 2001: 20-24; Günay 2014: 405). Geleneksel dini yaşam biçimine ait değerlerin ticari bir meta olarak tasarlanmasıyla geleneksel ve Batılı yaşam biçimi iç içe girer. Böylelikle dini yaşam yapıları ticari bir nesneye dönüşür ve tüketim kültürü normlarına göre yeniden yapılandırılır. Bu yönüyle Batılı yaşam tarzı, dini yaşam biçimi içinde inşa edilir. Tüketim ile Batılı yaşam tarzındaki gibi dini yaşam şeklinde de farklı kültürel bir tabakaya aidiyetlik başlar. Fakat burada tüketim nesneleri deneyimsel dünyanın dışına çıkarak yeni bir ruh kazanır. İnsanlar bu metaları satın alınca o ruhu da satın almış olurlar. Ruh ve meta denkleminde dini değerler ile tüketim ürünleri arasındaki ilişki, tüketim örüntülerinin içerik ve görünüm şekilleri noktasında değişiklik arz ettiği varsayılırsa belirli düzeyde çözülebileceği düşünülebilir. Bu çerçevede dini yaşam tarzının muhtevasını popüler kültür ve moda değerleri oluştururken, simgesel görünümler aşkın değerlere gönderme yapar (Zorlu 2003).

Ancak İslami bir kültürden Batı tarzı bir kültüre geçişi yansıtan hayat tarzlarındaki ve estetik değerlerdeki değişimler, Türk toplumunda kültürel farklılaşmalarla birlikte toplumsal tabakalar var etmiştir. $\mathrm{Bu}$ değişimler; toplumsal dengesizliği ve gelir adaletsizliğini, ekonomik güç bakımından yorumlayan toplumsal sınıf kavramının yerine çok daha geniş kapsamlı yeni alanları da içine alan bir "simgesel sermaye" ve habitusu içeren bir statü grubu kavramını zorunlu kılmıştır (Göle 2011: 103). Göle'nin bu tespitine asimetrik bir okuma yapılırsa; Batılı yaşam biçimini dinsel desenler barındıran bir yaşam biçimine kaydıran tüketim alanlarından söz edilebilir. Tüketim biçimlerinin ve ürünlerinin etkisiyle habituslar arasında bir arayış ve alışveriş gerçekleşmektedir. Bu bağlamda sınıf ve statü temelli bir sosyal çözümlemenin yetersiz kaldığı postmodern dönemde habitusların sınırlarının çizilmesinde ve bu sınırların kalıcı olmasında kutsal değerlere de rol verilmiştir.

SEFAD, 2018 (39): 311-326 
Kutsal değerlere biçilen rol, postmodernizmin dine bir alan açmasına neden olmuştur. Modernliğin kırılgan hale getirdiği toplumsal gerçekliğin onarılmasında görev verilen din (Kurt 2014: 232), dünyanin yeniden büyülenmesinde (Jameson 2008) hem postmodernizm tarafından araçsallaştırılması hem de kendi iddiasını postmodernizmin araçlarıyla ifade etmesi bakımından tüketimin yeni istimlâk alanlarında uzlaştırıcı bir misyon yüklenmiştir. Teknolojideki ilerleme, akıllı telefonlar ve onunla birlikte internetin hizla yayılması postmodernitenin ideolojik kavşağında kutsal ve seküler olanın kontrolsüzce çarpışmasına neden olmuştur. Bunun sonrasında her iki tarafın kimliksel söylemlerini üreten klasik yorumlarda tahribat meydana gelmiştir. Teknolojik yenilikler dini tüketim biçimlerine baştan şekil vermiş, teknoloji firmaları dine ve dinsel olana tamamen gözünü kapamamıştır. İnternetin yaygınlaşmasıyla sosyal ağlardaki dini paylaşımların artışı ve televizyonlarda dini programların izlenme oranları, tüketimin bu yeniden sunumlarının örnekliklerini oluşturmaktadır. Bu bağlamda televizyon kanallarında sıkça boy gösteren hocaların çok konuşulur olması, sosyal medyada binlerce kişi tarafından takip edilmesi ve onlarca uydu kanalı üzerinden dini malzemelerin pazarlanması, "filizlenmekte olan kapitalizmin hayati özelliklerinden biri bu yaşananların dini inancın canlanışıla paralel yürümesidir" diyen Vali Nasr'1 (2012: 31) doğrulamaktadır. İnsanlar bir taraftan dini olanı tecrübe etmekte ve tüketmekte, bir taraftan da yaşam kalitesini artıran malları ve hizmetleri talep etmektedir. Tüketimle birlikte dini olanın medya aracılığıyla daha görünür hale gelmesi ve insanların sosyal medya vasıtasıyla dinselliğini gösterme isteği, neşriyattan turizme kadar birçok alanın yeniden yapılanmasına neden olmaktadır. Bu yazının merkezinde yer alan kitap sektörü, dinin tüketim temelli postmodern bir dinsel tutum ve davranışlardan bağımsız davranmadığı görülmektedir. Sözgelimi bir yazarın kitabında dinsel bir anlam yüklediği yüzük veya kolye kısa süre içinde satışa sunulmaktadır. Yine Mevlânâ Yılı'na özel üretilen takı seti, Şems Hoşgörü Koleksiyonu ismiyle piyasaya sürülen vav harfli yüzük ve kolyeler bu konuda verilebilecek örneklerdendir (Hürriyet Gazetesi 2007).

Bunlar daha çok tüketimin postmodern istimlâk alanlarında görülmüştür. Bell'in (2014) ifade ettiği kutsalın dönüşü, Türkiye özelinde tüketim ürünleri üzerinden gerçekleşmiştir. Fakat Bell'in kastettiği kutsal, bir bütün olarak dönmezken parçalara ayrılarak ve farklı araçlara eklemlenerek bireylerin hayatına dönüş yapmıştır. Kutsalın parçalara ayrılıp metalaştırılması ise, "ihtiyaç fazlası din" anlayışının temel paradigması olmuştur. Dinin ihtiyaç fazlası olan tarafı, insanların gereksinim duyduğu kısmın dekoruna yerleştirilir. Yine kutsalın parçalanması, dinin morfolojisinin müsaade ettiği ölçüde çeşitli tüketim araçları üzerinden geri dönmesine izin verilir. Sözgelimi kitap sektöründe tasarımından içeriğine kadar dini temalı eserler piyasa sürülmüştür. Katı radikal seküler söylemin gücünü yitirmesiyle beraber Türkiye'de dini olana ilgi gün yüzüne çıkmıştır. Ancak toplumsal zeminde radikal seküler tutumun baskısına karşı daha önce direnç noktası oluşturan dini semboller, kişilikler hâkim söyleme göre törpülenmiştir. Muhafazakâr bir kimliğe sahip olduğu kabul edilen yazarlar bile seküler yaşam biçiminin ağırlıkta olduğu kesimlerin ihtiyaç duyacağı bir Mevlânâ portresi çizmiştir. Böylece dini semboller -sembolik bir görüntüde de olsa- postmodernizmin getirdiği yeni piyasa tekniklerine uyum sağlamıştır. Örneğin kişisel gelişim konularına da değinen bu dini içerikli kitaplar, sadece dini hassasiyeti olan yazarlar tarafından değil kendisini ateist olarak tanımlayan yazarların da ilgi alanına girmiştir. Öyle ki bu alanda Baudrillard'ın ifadelendirişiyle "tüketim toplumunun nahif bir öyküsü" anlatılmıştır (Baudrillard 2008: 151). 
Müslüman toplumlardaki bu nahif hikâye, insanların yaşam tarzları ve tüketim pratikleri üzerinden İslam'ın değişen yorumlarına bağlı olarak devamlı çeşitlenmektedir. Din bakımından seküler ve dinsel olan arasında doğrudan bir karşıtlık yaşanmaz. İnsanlar seküler ve dinsel olan arasında bir tercihte bulunurken herhangi bir iç çatışma yaşamaz. Çünkü insanlar, seçim yaparken dinin katı anlaşılma biçimine göre değil, içinde bulundukları koşullara uygun seküler ve dinsel olan arasına kalın sınırlar çizmeden hareket etmekte (Özbolat 2015: 84) hatta ikisini de aynı anda tercih edebilmektedir.

Dinin toplumsal çizgideki bu yeni konumlandırılışı, "bireysel inanç", "ideoloji” ve "kültür" parantezlerinde dine yeni mana ve görev belirlemiş, ancak nihayetinde onun ikincil pozisyonunu tahkim etmiştir. Bu bakımdan dinin bünyesinde bulunduğu hümaniter sınırlarda oluşturulan toplumsal gerçeklik alanında, pratikten ziyade bireysel inancı önceleyen; buna karşın bir tarafıyla da tüm soruları cevaplayan ideolojik; iddia ve taleplerin seviyesinin düşürülerek folklorik kılındığı kültürel din anlayışları türemiştir. Böylelikle din, sadece inanç seviyesinde, yerine göre ideolojik özellikler göstererek ve kültürleşerek bu toplumsallığı yürürlüğe koyma adına daha düşük bir profille görev almıştır (Tekin 2003: 21).

Dinin kültürleşmesi bir yönüyle postmodernizm ve edebiyat ilişkisi içinde konuşulabilecek bir meseledir. Postmodernizm öncelikle, bir edebiyat verimi olan romanda kendisini göstermiştir. Seksen sonrası metnin öncelendiği romanlarda postmodern anlayış kendini hissettirmeye başlamıştır. Yazarlar birbirinden farklı metinleri, montaj ve kolâj teknikleriyle bir araya getirerek oluşturabildikleri için (Çetişli 2004: 113) dönemin mevsimsel havasına uyum sağlayacak hızda eserler üretme imkânına sahip olmuşlardır. Bilhassa Mevlânâ'yı konu alan eserler, Mevlânâ'dan yaptıkları alıntıları eserlerine montaj ve kolaj tekniğiyle yerleştirmişlerdir. Ancak bu tekniklerin bünyesinde taşıdığı kırılganlık, kolay parçalanabilirlik sözü edilen romanlarda parçalı bir Mevlânâ görünüme sebebiyet vermiştir.

\section{METINLER ARASILIK VE DINNLER ARASILIKTA TÜKENMEYEN BİR HAZINENIN TÜKETIMI}

Mevlânâ'yı konu edinen eserler Mustafa Tekin tarafından üç kategoride sınıflandırılmıştır. İlk kategoride Mevlânâ fıkhın şekilci yönünü yumuşatan akıl ve kalbi birleştiren yönüyle ele alınır. İkinci kategoride politik ve dünyevi görüşleri nedeniyle Mevlânâ ile zıtlık teşkil eden kimselerin yazdığı olumsuzlayıcı eserler yer alır. Üçüncü kategoride ise popülist yaklaşımlar yer almaktadır. Üçüncü kategorideki yaklaşımlarda Mevlânâ, efsanevi bir kahramana dönüştürülmekte, olağanüstü olayların öznesi olarak anlatılmaktadır. Bu anlatılarda tarihi gerçekliğin efsaneleri üzerinden Mevlânâ'nın mitolojik boyutu pekiştirilmektedir (Tekin 2012: 21-23). Mevlânâ yazarlar için özellikle romancilar açısından da paylaşılamayan bir değer olmuştur. Mevlânâ'nın bu kadar çok esere konu olması, toplumun büyük bir bölümünde söylemlerinin karşılığının bulunması dolayısıyla kitap satış rakamlarına olumlu katkı yapmasıyla da ilintilidir. Dahası etkisini Mevlânâ'dan alan cümlelere yaslanmaya duyulan ihtiyaç, yazarları metinler arası bir ilişkiyle zorlamıştır.

Metinler arasılıkta; yaşam, kurmaca-gerçeklik karşıtlıklarının birbirine karıştığı ya da aynı anda yaşandığı, "çoğulcu" (pluralist) ve "eşzamanlı" (simultaneous) bir gerçeklik anlayışıyla birbirinden farklı metinler, bir araya getirilerek oluşturulur (Ecevit 2016: 100). Metinler arasılık, postmodern romanlarda teknik bir özellik iken bu araştırmanın konusu olan romanlarda yazarlara tarihten üretilen gerçekliği çağdaş bir ambalaj içinde topluma sunma imkânı sağlaması (Serdar 2001: 172) nedeniyle dinler arası ve mezhepler üstü bir zeminde kullanışlı bir araçtır. Bu bakımdan yazarlar, Mevlânâ gibi tarihsel, mistik bir 
kişiliğin fikirlerini, sözlerini kurgu süzgecinden geçirerek romanlara monte eder. Zira E. M. Forster' in (2001: 86) altını çizdiği gibi tarihçi, görevi gereği olanı yazarken romancının görevi yaratmaktır. Tarihçinin algılaması dışında olan ihtiras, ihanet, aşk, intikam gibi insan gerçeğini oluşturan duygular tarihçinin değil romancının ilgi alanındadır (Argunşah 2016: 64).

Araştırma kapsamındaki romanların en önemli içerik sağlayıcılarından olan tarih, romanlarda kurgu ve gerçekliğin, soyut ile somutun harmanlandığı bir şekilde aktarılır. Yazarlar bu romanlarda ana karakterlerin hikâyeleri üzerinden ideal bir dünya oluşturur. Ancak yazarlar romanlarını -bütünüyle tarihsel gerçekliğe hapsetmeden- kurgularken okurların hayal kurabileceği boşluklar bırakır. Özellikle Mevlânâ'dan söz eden romanların seslendiği okur kitlesi, yazarlar metnin kurgusallığına göndermelerde bulunsa bile bu metinleri tarihsel ve dinsel bilgi kaynağı olarak görme eğilimindedir.

Okurların zaviyesinden bakıldığında bu hakikat duygusunun kurgunun bir adım önünde geldiği söylenebilir. Okurda oluşan bu his romancının başarısını gösteren bir kıstas olarak lanse edilebilir. Örneğin Sinan Yağmur, Aşkın Gözyaşları Hz. Mevlâna kitabının sonundaki teşekkür bölümünde Tebrizli Şems kitabının okurdaki yansımaları hakkında şöyle yazmıştır: "Sayısız mesajlar, mektuplar, telefonlar geliyor: Hocam ne yaptınız siz? O dönemi yaşadınız, sonra öldünüz, tekrar dirilip de mi yazdınız? Nedir bu tesirli sırrın hikmeti? Sorular... Tebrikler... Teşekkürler... Gözyaşları... Dualar..." (Yağmur 2011b). Bab-ı Esrar ve Aşk romanlarında da Mevlânâ'dan aktarılan metinler, romanın kurgusallığının önüne geçerek okurdaki gerçeklik duygusunu kuvvetlendirir. Romanların kurgusallığını perdeleyen bir başka husus her üç romanda da kitap sonunda kaynakçaya yer verilmiş olmasıdır. Romanların kaynakça bölümü yazarın kitabı yazarken harcadığı emeği ve kitaba verdiği önemi de gösterir. Ancak bu romanlar söz konusu olduğunda bir taraftan kaynakça ile yapılan gerçeklik gösterisi bir taraftan romanlardaki kurgusallık vurgusu okurdaki kafa karışıklığını artırır. Bu kafa karışıklığı içinde okur, zihnindeki Mevlânâ'nın peşine düşer.

Okura çizilen bu kurgusal güzergâh metaforik öğelerle gizlenir. Bab-ı Esrar'da gümüş yüzük (Ümit 2008: 36), ayna (Ümit 2008: 56); Aşk'ta nehir (Şafak 2009: 11), ipekböceği koza ilişkisi (Şafak 2009: 111); Aşkın Gözyaşları'nda kozayı yırtan kelebek (Yağmur 2012: 213) gibi geçişler okura eşlik eder. Bu öğeler, aynı zamanda okurun metinler arası geçişini kolaylaştırır.

Araştırma kapsamındaki romanlarda iki veya daha fazla metin arasındaki gelgitlerin dinler arası ve mezhepler üstü bir misyonu vardır. Elif Şafak; roman, yazı ve söyleşilerinde dinler, kültürler arası karışımı sürekli tekrar eder. O, eserlerindeki fikri alt yapısını ve anlatım biçimini geleneksel ile modernin, Doğu ile Batı'nın, İslam ile diğer dinlerin alışverişi üzerine kurar. Hatta o, Alman Der Spıegel dergisinde (2016) "anneannesinin ölümüyle Türkiye'nin de öldü̆ğünü" ifade ettiği bir yazısında Türkiye'de dinler/kültürler arası alışverişin tükendiğinden dolayısıyla farklılıkların gittikçe kaybolduğundan söz eder. Elif Şafak'ın romanında dinler ve kültürler Mevlânâ şemsiyesi altında bir araya getirilir. Mevlânâ'daki tasavvuf düşüncesini "ben" ve "sen" $i$ bütünleyen "biz"i kimlik meselesinde araştıran Şafak, değişik kültürlerin birlikte uyum içinde yaşaması anlamına gelen çok kültürlülük olgusunu romanlarının temeline yerleştirir (Sazyek 2013: 206). Şafak'ın (2009: 226) mekânı Anadolu; "dinlerin, inançların, âdetlerin, masalların karışımı bir alaca diyardır." Şafak, Mevlânâ'nın hanımı Kerra'nın dilinden "Hıristiyanlıkla Müslümanlık arasında bir sinır kapısı varsa, bunun her iki taraftaki bağnazların iddia ettiği gibi geçilmez bir hudut" olmadığını aktarır. "Konya'nın Yahudi mahallesinde, bir Hiristiyan'ın meyhanesinde, her inançtan her mizaçtan" (Şafak 2009: 167) 
demkeşler neşe içinde kadeh kaldırdıklarında aralarındaki ayrılıkları da kaldırır. Aşk'ta Meyhane, özgürleştirici; farklılıkları birleştirici yönüyle inşa edilirken cami ötekileştirici ve kadınların dışlandığı hatta dövüldüğü bir mekân olarak tasvir edilir.

Aşk romanında olduğu gibi Bab-ı Esrar'da da Şemsle tanışmasından sonra Mevlânâ, Batılı okurların tasvip edeceği bir noktada caminin dışına çıkarılır. Mevlânâ Şems'le tanıştıktan sonra "namazı, vaazı, medreseyi bırakmıştır" (Ümit 2008: 157). Bir dine aidiyetlik oluşturması bağlamında cami steril bir alan değildir. Bu noktada yazarlar Mevlânâ ve Şems'i daha tarafsız bir alanda göstermeye gayret etmişlerdir.

Ahmet Ümit, Bab-ı Esrar'da Tanrı anlayışı üzerinden bir dinler üstülük vurgusu yapar. Eserde Tanrı, Berger'deki "sosyal inşacı" bakış açısıyla "mesele Tanrı'nın ne olduğu değil, bizim onda ne gördügüüüzdür" (Ümit 2008: 33) ve dolayısıyla Tanrı "gerçekliğin üzerine yükseltilen kuleler şeklinde" (Berger-Luckmann 2008: 59) "insani bir girişimdir" (Berger 2015: 85). Dahası Tanrı, kötülük problemi eşliğinde gündeme getirilirken Susan, Tanrı'nın salt belli bir dine ait olmadığını söyler. Ona göre Tanrı dinler üstü bir varlık olmalıdır.

\footnotetext{
"Sadece Hiristiyanların Tanrısı olamaz. Aynı zamanda Yahudilerin, Müslümanların, Budistlerin, Zerdüştlerin, Şamanların, hatta dinsizlerin bile Tanrısı olmalı. Ama anlamadığım şey, o yüce Tanrl, neden bu kadar duyarsız? Neden savaşa, açlı̆̆a, hastalı̆̆a çare bulmuyor? Neden bu kadar actya, vahşete göz yumuyor?" (Ümit 2008: 61).
}

Bununla birlikte inançları sorgulayan tek bir dine ait Tanrı anlayışının karşısında olan Susan ile Mevlânâ öğretisini benimsemiş Poyraz aynı çatı altında yaşamaktadır. Ümit'in Mevlânâ'yı konumlandırdığı nokta, halkı cehennem ile korkutan fıkıh kurallarına sıkı sıkıya bağlı, hayatını günah ve sevap merkezli yaşayan "Ortodoks İslam'ın” karşısındadır. Onun bu tavrı, Erol Güngör'ün ifade ettiği gibi Hıristiyan din adamlarının modern hayata yönelik yaptığı şikâyetlerin benzerlerinin Müslümanlar tarafından da yapılmasını (Güngör 1998: 206) başka bir deyişle Cumhuriyet Dönemi'nde dinin sevap ve günah merkezli toplumsal kontrol mekanizmasından duyulan rahatsızlığı hatırlatır. Bu rahatsızlık, romanlarda zaman zaman bir tartı̧̧ma konusu olarak gündemimize giren müzik üzerinden karşılık bulur. Müzik dinlerken "ezan okunuyor biraz sussana" uyarısı karşısında araya giren ve "bu da bir ezandır" diyerek müzisyenin susmasına engel olan (Ümit 2008: 349); "müzik, dans ve dua üçlemesinin" patent sahibi (Şafak 2009: 328); "geliştirdiğiniz mistik raks şeriate uygun değildir, yasaklansın" diye itham edilen (Yağmur 2011a: 171) bir Mevlânâ portresi, yazarları aynı konu üzerinde birleştirir.

Müzik konusunda Ümit ve Şafak'la aynı noktada buluşan Sinan Yağmur, Mevlânâ ve namaz ilişkisinde diğer iki yazardan ayrılır. Ahmet Ümit ve Elif Şafak, romanlarında Mevlânâ'nın namaz ibadetiyle ilgili bir sahnesine yer vermezken Sinan Yağmur'un Bab-ı Esrar ve $A s ̧ k^{\prime}$ taki bu eksikliği gidermek için namaz sahnesini sıkça tekrar ettiği düşünülebilir. Yazarlar arasındaki bu farklılıkların, onların Mevlânâ üzerindeki tasarruflarının hitap ettiği kitleye göre şekillendiği söylenebilir. Buna rağmen her üç yazarda da Mevlânâ'nın kapsayıcı bir dille takdim edildiği görülür. Elif Şafak'ta dinler arası, Ahmet Ümit'te dinler üstü bir konumda anlatılan Mevlânâ, Sinan Yağmur'da ise mezhepler üstü bir kimlikle sunulur.

\section{MEVLÂNÂ CELALEDDIN-İ RÛMÎ'NIN POSTMODERN ANLAYIŞTA KULLANIM ALANLARI}

Modern pazarlama, daha genel olana yönelirken postmodern pazarlama tüketim nesnesinin toplumdaki her bireye hitap edecek bir yönü olduğu kabulüne dayanır. Modern pazarlama yönteminde ürüne yönelik bir beğeni varken postmodern pazarlamada tüketici 
odaklı bir anlayış vardır. Rekabetin daha az olduğu, tüketici davranışlarının kolaylıkla saptanabildiği bir dönemden tam aksi bir sürece geçilmiştir.

Tüketici davranışlarındaki belirsizlik hususiyle 1990'dan itibaren kültür sanat başta olmak üzere postmodernizmin nüfuz ettiği her bölgede anlam, "eskiden var olan gizli, elitist zorluklarından kendini kurtarı" " herkesin görüp anlayabileceği bir seviyeye çekilmiştir (Mcrobbie 1998: 2). Roman yazarları açısından daha geniş kitlelere seslenmeyi hedefleyen bu anlayışta okur, ön plana çıkarılır. Onlar için okurlar biricik ve vazgeçilmezdir. Yazarla okurun arasında doğrudan ve dolaylı olarak oluşturulmuş imaj köprüleri kurulur. Diğer bir ifadeyle yazarlar kullandıkları dil ve üslup ağı ile okurlara ulaşmayı amaçlar.

Öte yandan kültür endüstrisinin bir parçası olan yayın dünyasında mevcut koşullar, yazarları oldukça zorlamaktadır. Yayın dünyasında üretim ve tüketim çarkı çok hızlı döndüğü için okurla buluşmuş bir eser büyük reklamlara, tanıtımlara rağmen kısa sürede gündemden düşmektedir. Örneğin bir romanın edebiyat dünyasında konuşulması iki üç ayla sınırlı kalmaktadır. Yine bir yazarın gündemde kalabilmesi için daha fazla eser vermesi gerekmektedir. Metinlerin kısa sürede yazılması icap ettiğinden tarihi kaynaklardan aktarım yapılabilecek alanlardan nispeten yüzeysel eserler ortaya çıkmaktadır.

Kolay ve çabuk yazılan bu romanlarda insanların hayatında tarihin her döneminde önemini korumuş "aşk", "din" ve "mistisizm" mevzuları gündeme getirilir. Bu konular, yazarlar tarafından ya hayali bir kahraman ya da tarihsel gerçekliği olan bir kişilik çevresinde işlenir. Mevlânâ bu bağlamda aşk, din, mistisizm gibi popüler uğraklardan müteşekkil romanlarda okuyucuya yol göstericidir. Daha açıç̧ası söz konusu eserlerde toplum, Mevlânâ vasitasıyla tüketime yönlendirilmektedir. Ömer Türkeş'in Karl Marx'tan aktardığı gibi üretimin tüketim için yarattığı tek şey nesne değil; tüketime özgüllüğünü, biçimini, karakterini vermesidir. Üretim yalnız nesneyi değil aynı zamanda tüketim tarzını da; yalnız nesne olarak değil, aynı zamanda öznel olarak da üretmektedir (Türkeş 2012: 270).

Mevlânâ'yı konu alan bu romanlarda tüketim tarzlarına etki eden profesyonel bir ekip desteği bulunmaktadır. Postmodern pazarlamanın mantı̆̆ına göre oluşturulmuş bir marka algısının canlı kalabilmesi için yazarların medyanın ve sosyal medyanın güçlü ambiyansıyla işbirliği yaptığı söylenebilir. Okura vaat edilen şeyler; yazarlar, kişiler, kitaplar, medyalar arası bir imaj dayanışması neticesinde afişe edilir. Gerek kitabın arka kapağında gerek daha başka mecralarda kitap veya yazar hakkında söz söyleyenler, söz konusu kitabın okurun hayatında meydana getireceği değişimleri önceden haber verir. Elif Şafak'ın (2009: 11) Aşk romanının önsözünde "göz açıp kapayıncaya kadar ufacık bir taş ne işler başa" diyerek göle düşen bir taşın okurun hayatında oluşturacağı etkiden söz etmesi; okurların fiziksel ya da duygusal ihtiyaçları marka vaadi olarak karşılık bulur (Ok 2013: 56).

Kitabın vaat ettiği duygusal ihtiyaçların bir bölümü romanın içeriğinde yer verilen ürünlere eklenerek kitapla birlikte piyasada dolaşıma çıkarılır. Roman kahramanının giyim kuşamı ve tercih ettiği ürünler, ticari değer kazanır. Romandaki "hayat tarzının" yanında "ev dekorasyonu", "yüzük", "kolye", "yelek" gibi birçok ürün pazarlanır. Elif Şafak'ın roman kahramanı Ella'nın viktorya tarzı ev dekorasyonu kadınlar arasında merak edilen bir konu olmuştur. Sinan Yağmur'un Aşkın Gözyaşları Kimya Hatun romanında çift vav ametist kolyenin gücüne Kimya tarafından özellikle vurgu yapılır. Kimya Hatun'da her bölüm başlı̆̆ında subliminal reklam diliyle çift vav görseline yer verilir. Ayrıca Sinan Yağmur'un katıldığı birçok programda üzerinde çift vav bulunan mor bir yelek giymesi hatta sosyal medya hesabında "mor yelekli adam" olarak tarif edilmesi tesadüf değildir. 
Makalede konu edilen her üç yazar da okurlarla yatay bir ilişki kurmayı tercih etmektedir. Sosyal medya, imza günleri ve geziler yazarlara okurla daha yatay bir ilişki ve iletişim kurma fırsatı verir. Zira yazarların okurlarla iletişim biçimleri onlarla kurdukları bağı güçlendiren bir faktördür. Ahmet Ümit, takipçileriyle romanlarında geçen mekânları birlikte gezmektedir. Elif Şafak, özel bir okur kitlesinin varlığından bahseder ve onlar Şafak için "ruhdaştır." (Habertürk Gazetesi 2011). Sinan Yağmur, okurlarına "canparalerim" diye hitap eder. Sinan Yağmur, Şems-i Tebrizi'nin yazılış hikâyesinde kitabın zirveye çıkmasında "aşka râm olarak okuyan, sevdiklerine hararetle tavsiye eden, aylarca kitabr elinden ve dilinden düşürmeyen okurlar cennet kokulu duaları ile rüzgâr oldular ve ilk 10 ayda 260. baskıya ulaştırdılar." demektedir (Yağmur 2011a). Sinan Yağmur'un okurla kurduğu bu yatay ilişki, anlatmış olduğu Mevlânâ imgesini perçinlemiştir. Onun 30.05.2012 tarihinde CNNTURK'te yayınlanan 5N1K programında (Özdemir 2012) “Aşkın Gözyaşları' na en az sahip çıan şehrin Konya en çok sahip çıkan şehrin İzmir olduğunu" vurgulaması ile kitabında "İzmir'den Canan Hanım'ın Şems-i Tebrizi'yi okurken dakikalarca ağladığına" yer vermesi, İzmir'in muhafazakârlık görünümü ve okur/tüketici tercihleri arasındaki bağıntıya yaptığı ironik gönderme arasında paralellik vardır. Sinan Yağmur'un iki şehir arasında kurduğu tezatlık, iki şehir üzerinden yapmış olduğu bu ironik hatırlatmaların ucu, hitap ettiği kitlenin genişliğine çıkar. Sinan Yağmur'un din dili ile İzmir arasında bağ kurması tartışılacak bir durum olsa da onun toplumun bir kesimindeki dinsel duyguya olan ihtiyacı değişken (tranzisyonel) dindarlık tipiyle giderdiği söylenebilir.

\subsection{Mevlânâ'nın Kadın Okuyucudaki Öyküsel Tüketimi}

Semih Gümüş, kitabı ucuz bir meta olarak pazarlamanın postmodernizmin yansımalarından biri olduğunu belirtmiştir. Ona göre popüler edebiyat, işlevsel dilin yazınsal dilin yerine geçmesiyle meydana gelmiştir (Gümüş 2015: 150). Dolayısıyla mevcut koşullarda ucuz olan daha fazla kişi tarafından satın alınabilir anlayışı öne çıkmıştır. Aksi takdirde kültür endüstrisinin kurallarını çiğnemek yazarı ve eserini yalnız bırakacak, yazarın unutulmasına neden olacaktır.

Bunun önlenmesi için roman karakterleri; onların hikâyeleri ve savundukları fikirler, kültür endüstrisinin bileşenleri göz önünde bulundurularak planlanır. Bab-ı Esrar'daki Ziya Bey, Solak Kamil; Aşkın Gözyaşları'ndaki Halep Valisi, Molla; Aşk romanındaki Şeyh Yasin, Bağdat Kadısı, Mutaassıp, Baybars gibi "kötü adamlar" bir taraftan soft ideolojiye işlerlik kazandırmış bir taraftan da romanların sinemaya aktarılması durumunda yapımcının elini güçlendirecek karakterler olarak tasarlanmıştır. Bu katı kuralcı, mutaassıp, maddiyatçı, yerine göre dini kendi çıkarları için kullanan; ikiyüzlü ve dolayısıyla kötü olan adamlar tarafından kuşatmaya alınmış kadınlar ve kuşatma çemberinin merkezindeki Mevlânâ idealize edilmiştir. Bununla beraber romanlarda kitlelerin beklentisine göre uyarlanan hikâyeler de anlatılmıştır. Bu hikâyelerin içinde tüketim ürünlerine planlı bir şekilde yer verildiği görülür. Bu sayede kitap sektörünün yan alanları, yazara ve romana lojistik destek sağlayarak romanın eleştirel bir sarsıntıya uğramaması için dalga kıran vazifesi görür.

“Oda sessiz... Sen sessiz. Ben sessiz. Sessizlik özündedir en koyu hüznün deminde.

Bilinmez özünde Hakk'a yürüyüşün hangi mertebesindesin, neresindesin bilinmez... Ben

ise bana verdiğin hükmü seninleyken sensizliği yaşıyorum... Yaşıyorum ama

yaşlanıyorum sessizliğimde... Yaşlıyım gözlerimde..." (Yă̆mur 2011b: 90).

Yazarların sıkça müracaat ettiği bu "dalga kıranlar" maddi tatminler yanında psikolojik veya simgesel göstergeler ile imaj ve duygu tatmini arayanlar için de bir

SEFAD, 2018 (39): 311-326 
sığınaktır. Simgesel tüketimin devreye girdiği Şems ve Mevlânâ üzerinden dinsel bir güç bahşedilmiş santimantal cümleler, arka arkaya sıralanarak okur şaşırtılır. "Gözlerimin siyahında dans eden dostumun hayali" (Ümit 2008: 131), "hep aynı yere kök salmış, hayatından bıkmış evli barklı kadınların kırk kuralı" (Şafak 2009: 309), "yüreğimden kopan bir elin parmak uçlarındaki zehri" (Yağmur 2011b: 218) gibi sifat ve zincirleme isim tamlamalarının kullanılması, okurun ruhsal durumuna ayna tutar. Bu şekilde tüketenle tüketilen arasında duygu bağları oluşturacak bir dil kullanan yazarlar, toplumdaki eksikliği keşfederek toplumun ihtiyaç duyacağı mikro boyutta özerk alanlar üretme potansiyeline sahip söylemlere yönelir. Esasında popüler dil ve tüketim ilişkisi bağlamında ele alınabilecek bu ifadeler, santimantal rollerin verildiği roman kahramanlarının diliyle aktarılır.

Romanlarda bu dilin öne çıarılması popüler kültürün ve edebiyatın ilgi alanlarının başında kadınların gelmesiyle ilgilidir. Gerek bir ürünün pazarlama aracı gerek hedef kitle olması noktasında popüler kültür, kadınları hep öncelemiştir. Tüketim ve harcama kültürünün araçsallaştırdığı kadın; tüketim toplumunda yalnızca biyolojik bir beden anlayışını değil, aynı zamanda simgesel olarak üretilmiş bir "sosyal beden" anlayışını da gerekli kılar. Bedenin postmodern tüketim kültüründe edindiği temel anlam "diğerlerinin bakışında" anlam kazanan, elle tutulur "maddi bir hakikattir" (Köse 2011: 77). Mevlânâ romanlarında kültürel, dinsel sermayenin çoğaltılmasını sağlayan tüketim araçları, sosyal beden hakikatine çok da derinlerde olmayan simgesel bir ruh katarken "diğerleri" tarafından da görülebilmesini sağlayacak "transparan bir görünüm" verir. Bu görünüm, okuru kışkırtır ve sosyal bedenin Mevlânâ'dan mülhem inşası için tüketime teşvik eder.

Makalede söz konusu üç romanda da sosyal beden hakikatiyle olumlanan ve olumsuzlanan kadın karakterler arasında kontrast tonlar oluşturularak mesaj verilir. Her üç romanda da "kadın bedeni" bizatihi romancının mesaj yükünü taşıyan önemli bir araçtır. Mevlânâ'nın anlatıldığı bu romanlardaki kadınlar, günümüz kadınlarının kadınlık refleksiyle hareket eder. İster geçmişte yaşayan bir kişilik olsun ister modern hayatın içinden birisi olsun bu romanlarda tipler, "kadın her yerde her zaman kadındır" mottosuyla konumlandırılır. Zayıflama derdinde, okutulması gereken, dedikoducu, evine bağlılığı ve fedakârlığı nedeniyle kendine zaman ayıramamış dolayısıyla değişime fırsat bulamamış, erkekler tarafından istismara uğramış hatta şiddet uygulanmış olanların yanında Mevlânâ dolayımında kendi ayakları üzerinde durma iradesine kavuşmuş kadınlar, bu makale kapsamındaki romanlarda yazarların ortaklaştıkları betimlemelerdir.

Tarihsel varlıklarından çok tarihsel gerçeklikleri tartışma konusu olan bu kadınların konumlandırılışı, popüler romanların kurgusal özgürlük alanlarındandır. Ancak romancı, başkahraman üzerinde yapacağı kurgusal tasarrufu kamuoyundan yükselecek tepkileri, akademik itirazları hesaplayarak yardımcı kadın karakterlere yönlendirir. Örneğin Elif Şafak'ın Aşk romanında ve Sinan Yağmur'un Kimya Hatun romanında Kimya, Şems'in karşısında duygusal olarak nesneleştirilir. Bab-ı Esrar'da Karen, Kimya'ya dönüşürken Şems'in baskın karakteri dikkat çekicidir. Bu romanlarda Şems'in yüceltilmesi Kimya'nın hayat hikâyesinin konusudur. Kimya, inceleme kapsamındaki her üç yazarda da Şems'in gölgesinde tasvir edilir. Neticede Kimya, karizmatik bir şahsiyetin eşi olarak bugünün kadınlarının kendi hikâyelerinin başkalarına dönük sosyal etkileşiminin prototipik örneği olarak sunulur. 


\section{SONUÇ}

Postmodernizmle birlikte meta anlatıların yanında söylemsel bazda büyük iddialara sahip fikir kalıpları çözülmeye uğramıştır. Modernitedeki büyük söylemlerin daha geniş coğrafi alanda ve daha çok nüfus üzerinde etkili olma iddiası postmodernizmin karşı koyuşuyla daha federatif bir yapıyı benimsemek zorunda kalmıştır. Berger'in modernitenin saldırılarıyla zayıflayan hatta çöken kuşatıcı anlam düzeni dediği durum neredeyse bir roman konusu haline gelmiştir. Berger'in kastettiği bu anlam düzeninin fay hatlarının kırılmasıyla tarihsel ve sosyal var oluşunu din olmadan da devam ettirebileceğine inanan modern insan tipi (Berger 2015: 52-53) özerk alanda dinden ziyade dinsel olan araçlarla ihtiyacını karşılamıştır. Modern insan tipinin anlam haritasında bu özerk alanlar bireylerin çeşitlenen ihtiyaçlarını kolaylıkla karşılayabilmesi için daha geçişken ve gevşek sınırlarlarla belirlenmiştir. Ancak bu simgesel, sosyal ve kültürel sınırların hayatiyetini devam ettirebilmesi bu sınırların asgari düzeyde de olsa meşrulaştırılmaya gereksinim duyması açısından soft bir ideolojiye ihtiyaç duyulmuştur.

Söz konusu romanlarda yazarların Mevlânâ bağlamında dile getirdikleri yaklaşımlara uygun olarak türetilen soft ideolojinin dinler üstü ve dinler arası bir zemine yerleştirildiği tespit edilmiştir. Bu ideolojinin kültür endüstrisi dikkate alındığında bir hayli kullanışlı olduğu gözlenmiştir. Aşk, aile, arayış, sır, samimiyet kelimelerinin köşe taşı olarak kullanıldığı öykü adacıklarından müteşekkil bu romanlarda ikili bir güzergâh izlenmiştir. Katı dini söylem sahiplerinde temayüz eden ikiyüzlü, aile bağları zayıf kişiliklerin öyküleri ile dini katı kurallarından bağımsız daha çok ahlaki tutarlılık üzerinden yaşayan kahramanların öyküleri yan yana anlatılmıştır. Bu hikâyelerde verilmek istenen mesajların taşıyıcı bir unsuru olması açısından kadın karakterler, bugünün kadın sorunları etrafında biçimlendirilmiş ve bu sayede yazarlar geçmişle bugün arasında bir bağlantı kurmuştur. Onlar; romanlardaki kadınların ilgileri, beğenileri, arayışları, duygusallıkları aracılığıyla bizatihi kadın okurlarla temas sağlamıştır. Bütün bu geçişlerde Mevlânâ, bugünün kadın sorununa yumuşak dokunuşlar yapan bir figüre dönüştürülmüştür. Mevlânâ'nın kadın sorunu gibi bir alanda yeniden inşa edilmesi, roman(cı)ların hedef kitlesinde kadınları ön sıraya taşımıştır.

Esasen bu yazarların kişisel üslubu ve hitap ettiği özel okur kitlesi, Mevlânâ'nın yönünü belirlemiştir. Mevlânâ'nın kullandığı sembolik dilin modernitenin katı kurallarını sorgulamak için kullanılmasının avantajının yanında bu dil ile dinin katı kuralcı yanı da esnetilmiştir. Tespih, takke, medrese, molla, şeyh, minder, altın bilezik, göbekli, kilolu roman kahramanları ikiyüzlülüğün sembolik unsurları olarak romanlarda kullanılırken yüzük ve kolye sadeliği, sırrı ve fantastiği temsil eden kirlenmemiş aksesuarlar olarak sunulmuştur.

Yazarlar, tarihsel ve dini bir gerçekliği bulunan bir şahsiyetin yazdıkları ve yaşadıklarından yeni bir kurgu ile kitlelerin beklentisine ve seviyesine uygun yapıtlar üretmiştir. Bu noktada romancılar, Mevlânâ'yı moderniteden arta kalan sorunlara postmodern çözümler getiren bir kişilik olarak somutlaştırmıştır. Hal böyle olunca Mevlânâ, popüler kültürün değerleri tüketen; Bauman'ın "akışkan modernizm" kavramsallaştırmasıyla tanımladığı bu çağda etkileyen ve etkilenen yanıyla diyalektik bir sürecin nesnesi konumuna getirilmiştir. Ancak Mevlânâ'nın popüler kültürün tüketim kabı içinde tamamen tüketilmediği görülmüş, geride Mevlânâ'yı çağrıştıran bir şeyler bırakılmıştır. Bu durumun romancılar için Mevlânâ ile fermente edilmiş kültür ürünlerinin üretimini ve sunumunu kolaylaştırdığ gözlemlenmiştir. 


\section{SUMMARY}

Mawlana Jalaluddin-i Rûmi is one of the most significant names of Turkish Islamic Mysticism. The influence of Mawlana's thinking and works is experienced throughout history. The period in which the researchers of Mawlana lived shaped their study in terms of content and form. As well as his thoughts and works, the studies about him attracted great attention. While studies about Mawlana are concentrated on his religious, mystical, philosophical and literary aspects at the present time, he is involved in novels as a hero/ character increases readers' attention to him. The authors who are well aware of this popular tendency towards Mawlana produce novels about him. However, authors reinterpret quotations from the works of Mawlana in their novels with their own styles. Authors who generally focus on how Mawlana would suggest solutions to today's current problems take advantage of his mystical power. After all Mawlana's mystical aspect in society and his updated narrative make sense according to the rate book selling. In this sense, on the one hand Mawlana is updated in accordance with society's needs in some works and while on the other hand he is abused by consumption with a new kind of narrative in some other works. In these novels, in accordance with the approaches that the authors have expressed in the context of the Mawlana, derived soft ideology that has been found to be placed on above religion and inter-religious ground. This ideology has been observed to be quite useful considering the culture industry. In novels supported by short stories about love, familial values, search, sincerity, etc.-especially for women-the mystical aspect is aimed.

The authors produced works from writings and experiences of Mawlana according to expectations and level of the masses with a new fiction. At this point, the novelists embody Mawlana as a personality that brings postmodern solutions to the remaining problems of modernity. In this case, Mawlana was used as the face ad of popular culture. How he is positioned as the object of a dialectical process with affecting and affected aspect. In this study the use of Mawlana as a postmodern consumption element in Ahmet Umit's Bab-1 Esrar, Elif Şafak's Aşk (The Forty Rules of Love: A Novel of Mawlana), Sinan Yagmur's Aşkın Gözyaşları, which achieve a notable sale results in the market is examined. This article aims to analyses the consumption-centric handling of Mawlana with a postmodern discourse due to the interest of historical and mystical novel characters.

The article is limited to the novels Bab-1 Asrar, Aşk (Love) , Aşkın Gözyaşları (Tears of Love). The article is divided into three main sections. The first chapter focuses on how Postmodernity has installed a mission to religion in the consumption process. In the second chapter, quotations from Mawlana are discussed in the points that the authors merged and separated about it. In the third part, we consecrated on popular view about types of authors relationship with readers in their daily life. In addition to this, how the authors were affected by Mawlana who positively contributed to their literacy while communicating with the readers? Mawlana's portraits that is related to above religions and above sects are created from which perspective? These are the questions that we are looking for answer. In the methodological framework of the research, Berger's phenomenological method is an important place. 


\section{KAYNAKÇA}

Argunşah, Hülya (2016). Tarih ve Roman. Ankara: Kesit Yay.

Baudrillard, Jean (2008). Tüketim Toplumu. çev. Hazal Deliçayl1-Ferda Keskin. İstanbul: Ayrintı Yay.

Bauman, Zygmunt (2011). Postmodern Etik. çev. Alev Türker. İstanbul: Ayrıntı Yay.

Bauman, Zygmunt (2012). Küreselleşme. çev. Abdullah Yılmaz. İstanbul: Ayrıntı Yay.

Bauman, Zygmunt (2017). Akışkan Modernite. çev. Sinan Okan Çavuş. İstanbul: Can Yay.

Bell, Daniel (2014). Kutsalın Dönüşü. çev. Ali Köse. İstanbul: Timaş Yay.

Berger, Peter L (2015). Kutsal Şemsiye. çev. Ali Coşkun. İstanbul: Rağbet Yay.

Berger, Peter L.-Luckmann, Thomas (2008). Gerçekliğin Sosyal İnşası. çev. Vefa Saygın Ögütle. İstanbul: Paradigma Yay.

Berger, Peter L.-Luckmann, Thomas (2015). Modernite, Çoğulculuk ve Anlam Krizi. çev. Mustafa Derviş Dereli. İstanbul: Heretik Yay.

Börekçi, Gülenay. "En Derin Yaralar Ailede Açlır". http://www.haberturk.com/kultursanat/haber/651253-en-derin-yaralar-ailede-acilir [15.01.2017].

Çetişli, İsmail (2004). Metin Tahlillerine Giriş 2: Hikâye-Roman-Tiyatro. Ankara: Akçağ Yay.

Çiftçi, Adil (1999). Toplum Bilim Yazıları. İzmir: Anadolu Yayın Dağıtım.

Ecevit, Yıldız (2016). Türk Romanında Postmodernist Açıllmlar. İstanbul: İletişim Yay.

Emre, İsmet (2004). Postmodernizm ve Edebiyat. Ankara: Anı Yay.

Featharson, Mike (2007). Consumer Culture and Postmodernism. London: Sage Publication.

Forster, Edward Morin (2001). Roman Sanatı. çev. Ünal Aytür. İstanbul: Adam Yay.

Göle, Nilüfer (2011). Melez Desenler. İstanbul: Metis Yay.

Gümüş, Semih (2015). Modernizm ve Postmodernizm. İstanbul: Can Yay.

Günay, Ünver (2014). Din Sosyolojisi. İstanbul: İnsan Yay.

Güngör, Erol (1998). İslam'ın Bugünkü Meseleleri. İstanbul: Ötüken Yay.

Hürriyet Gazetesi. "Mevlânâ yılına özel takı koleksiyonu:

Hoşgörü". http://www.hurriyet.com.tr/mevlana-yilina-ozel-taki-koleksiyonu-hosgoru$\underline{5728080}$ [26.01.2017].

İbn Haldûn (2009). Mukaddime. çev. Süleyman Uludağ. İstanbul: Dergah Yay.

Jameson, Fredric (2008). Postmodernizm ya da Geç Kapitalizmin Kültürel Mantığı. çev. Nuri Plümer-Abdulkadir Gölcü. Ankara: Nirengi Kitap.

Köse, Hüseyin (2011). "Tüketim Toplumunda Bir 'Sosyal Beden' Kurgusu Olarak Kadın". Selçuk İletişim Dergisi 6 (4): 76-89.

Kurt, Abdurrahman (2014). Din Sosyolojisi. İstanbul: Sentez Yay.

Mcrobbie, Angela (1998). Postmodernism And Popular Culture. London: Routledge.

Nasr, Vali (2012). İslami Sermayenin Yükselişi. çev. İhsan Durdu. İstanbul: Ufuk Yay.

Ok, Şaban (2013). Ilk Marka Hz. Adem mi?. Ankara: Elma Yayınevi.

Özbolat, Abdullah (2015). Kapitalizme Eklemlenme. Adana: Karahan Kitabevi.

Özdemir, Cüneyt (2012). Aşkın Gözyaşları Kitabı'nın Yazarı Sinan Yağmur 5N1K'da. https://www.youtube.com/watch?v=tCbkW39gtP8 [15.01.2017].

Özdoğan, Muhammet Ali (2017). Çağdaş Türk Romanında Mevlânâ'nın Postmodern Bir Tüketim Unsuru Olarak Kullanılması. Yüksek Lisans Tezi. Antalya. Akdeniz Ü.

Sazyek, Esra (2013). "Elif Şafak'ın Romanlarında Çok Kültürlülük Aracı Olarak Tasavvuf". Bilig 66: 205-208.

Serdar, Ziyaüddin (2001). Postmodernizm ve Öteki. çev. Gökçe Kaçmaz. İstanbul: Söylem Yay. Şafak, Elif (2009). Aşk. çev. Kadir Yiğit Us. İstanbul: Doğan Kitap.

SEFAD, 2018 (39): 311-326 
Şafak, Elif (2017). "Meine Türkei ist so tot wie meine Großmutter". Der Spıegel. http://www.spiegel.de/kultur/literatur/tuerkei-elif-shafak-ueber-die-lage-nachdem-reina-terroranschlag-a-1129285.html [11.01.2017].

Tekin, Mustafa (2003). Kutsalın Serüveni. İstanbul: Aç1lım Kitap.

Tekin, Mustafa (2012). Mevlana Pergelinde Toplum. İstanbul: Rağbet Yay.

Türkeş, Ömer (2012). “Küreselleşme Sürecinde Türk Romanının Sosyolojik Analizi”. Edebiyat Sosyolojisi. ed. Köksal Alver. Ankara: Hece Yay. 263-305.

Ümit, Ahmet (2008). Bab-ı Esrar. İstanbul: Doğan Kitap.

Weber, Max (2004). Sosyoloji Yazıları. çev. Taha Parla. İstanbul: İletişim Yay.

Yağmur, Sinan (2011a). Aşkın Gözyaşları Hz. Mevlâna. Konya: Karatay Akademi Yay.

Yağmur, Sinan (2011b). Aşkın Gözyaşları Kimya Hatun. Konya: Karatay Akademi Yay.

Yağmur, Sinan (2012). Aşkın Gözyaşları Tebrizli Şems. Konya: Karatay Akademi Yay.

Zorlu, Abdulkadir (2003). "Batılı Bir Yaşam Tarzı Olarak Tüketim: Türkiye'de Tüketim Ürünlerinin ve Kültürünün Tarihi Gelişimi". Hacettepe Üniversitesi Sosyolojik Araştırmalar E- Dergi. http://www.sdergi.hacettepe.edu.tr/makaleler/zorlu makale.pdf [12.12.2017]. 